\title{
Total Phenolics and Antioxidant Capacity of Some Nigerian Beverages
}

\author{
*H. A. Oboh and I P. Omoregie \\ Department of Medical Biochemistry, School of Basic Medical Science, College of Medicine, University of \\ Benin, Benin City, Edo State, Nigeria. \\ [*Ccorresponding Author: Email: hettyoboh2002@yahoo.com; Tel.: +234-8023168660, +234-8038171016]
}

\begin{abstract}
The aqueous extract of Nigerian beverages namely: fortified cocoa powder (Samples;
$\left.\mathrm{FC}_{\mathrm{A}}, \mathrm{FC}_{\mathrm{B}}, \mathrm{FC}_{\mathrm{C}}, \mathrm{FC}_{\mathrm{D}}\right)$ Pure cocoa powder $\left(\mathrm{PC}_{\mathrm{A}}, \mathrm{PC}_{\mathrm{B}}\right)$, coffee $(\mathrm{C})$, ginger $(\mathrm{G})$ and Tea samples (Green, TA, TB) were assayed for total phenols, flavonoids, Vitamin $\mathrm{C}$ and radical scavenging abilities using four different in vitro antioxidant assay methods. Coffee contains the highest amount of total phenols $(135.71 \pm 0.92 \mathrm{mg} / \mathrm{g})$ and Vitamin C. $(62.90 \pm 2.97 \mathrm{mg} / \mathrm{g})$. The highest amounts of flavonoids were found in all the tea samples $(10.0 \pm 0.00 \mathrm{mg} / \mathrm{g})$. Green tea and coffee had the highest 2, 2-diphenyl-1-picrylhydrazyl radical [DPPH] radical scavenging ability. Green tea also had the highest radical scavenging ability as measured by the 2, 2-azino-di-[3-ethylbenzothialozine-sulphonic acid] [ABTS] radical scavenging ability and ferric reducing antioxidant property [FRAP]. $(1.04 \pm 0.037 \mathrm{mg} / \mathrm{g}$ and $1235.88 \pm 22.67 \mathrm{mmol} / \mathrm{g}$ respectively). Cocoa powder $\left(\mathrm{PC}_{\mathrm{A}}\right)$ had the highest iron II chelating ability $(38.46 \pm 2.72 \mathrm{mg} / \mathrm{g})$. The total phenolic content of the beverages had good correlation with total flavonoids, DPPH, ABTS and FRAP radical scavenging abilities with $r$ values higher than 0.7. Vitamin $C$ assay correlated well with DPPH free radical scavenging ability assay $(\mathrm{r}=0.73)$ while iron (II) chelation ability correlated fairly with vitamin $\mathrm{C}(\mathrm{r}=0.43)$. The results suggest that the beverages possess significant radical scavenging ability that may be due to the presence of the antioxidant.

Keywords: Phenolics, flavonoids, Vitamin C, radical scavenging , antioxidant Green tea and coffee .
\end{abstract}

\section{INTRODUCTION}

Excessive accumulation of free radicals results in oxidative stress. This is one of the main causes of initiation and progression of diseases and premature aging (Yasin et al., 2010). The antioxidant system in healthy humans functions to scavenge free radicals and turn them to harmless particles (Silva et al., 2006). Adverse factors (stress, diseases, certain powerful drugs, environmental pollution, smoking, alcoholism, low quality food products, etc) increase free radical generation which could damage DNA, proteins, lipids carbohydrates and vascular walls (Sun et al., 2002). These could result in disorganization of normal processes in human bodies (Gutteridge and Halliwell, 2000).

Increased antioxidant intake may protect humans from diseases as oxidative events in vivo may play a role in the pathogenesis of many diseases which includes cancer, cardiovascular diseases and arthritis (Oboh and Rocha, 2007, Ghanim et al., 2010).
Plant foods rich in antioxidants have received a growing interest because they delay oxidative stress (Nicolle et al., 2004). The chemoprotective properties of phenols and flavonoids have been reported to include antithrombotic, pharmacological and hypolipidemic effects. (Dreosti, 2000).Vitamin C may also contribute to the maintenance of a healthy vasculature and a reduction in atherogenesis through regulation of collagen synthesis, prostacyclin production and nitric oxide (Aruoma, 2003).

Beverages (Coffee, tea and cocoa) contain polyphenols and flavonoids that have diverse beneficial biochemical and antioxidant effects (Buijsse et al., 2006; Schroeter et al; 2002). These beverages may play an important role in improving beneficial intestinal microflora, as well as providing immunity against intestinal disorders and in protecting cell membranes from oxidative damage (Ferrazzano et al., 2009).

The antioxidant effects of some beverages consumed has been reported (Pellegrini et al., 2003; Rawell and Kulling; 2007). 
Nigerian Journal of Basic and Applied Science (2011), 19(1): 68-75

This study aims to determine the total phenol, flavonoid and vitamin $\mathrm{C}$ contents in some Nigerian beverages and assess the free radical scavenging abilities of the aqueous extracts using four different in vitro assays.

\section{MATERIALS AND METHODS Materials}

Samples of beverages namely: Fortified Cocoa powder $\left(\mathrm{FC}_{\mathrm{A}}, \quad \mathrm{FC}_{\mathrm{B}}, \quad \mathrm{FC}_{\mathrm{C}}, \quad \mathrm{FC}_{\mathrm{D}}\right)$, pure cocoa powders $\left(\mathrm{PC}_{\mathrm{A}}, \mathrm{PC}_{\mathrm{B}}\right)$, coffee $(\mathrm{C})$, ginger $(\mathrm{G})$, teas: (Green, $T_{A}, T_{B}$ ), were purchased at both the Oba market and New Benin market in Benin metropolis, Nigeria.

\section{Preparation of Aqueous Extract}

The aqueous extract of the different beverages were prepared by adding $100 \mathrm{ml}$ of boiling water to $1 \mathrm{~g}$, stirred and left for five minutes. Thereafter, the mixtures were centrifuged at 500rpm for 5 minutes. The supernatant (aqueous extract) was collected and stored at $0^{\circ} \mathrm{C}$ until needed for analysis.

\section{METHODS}

\section{Evaluation of Antioxidant Activity}

A. 1, 1-diphenyl-2 picrylhydrazyl free radical scavenging ability [DPPH]

The free radical scavenging ability of the extracts against DPPH (1, 1-diphenylï 2 picrylhydrazyl) free radical was evaluated as described by Gyamfi et al. (1999). A 1:10 dilution of the extracts was prepared and $1 \mathrm{ml}$ of it was mixed with $1 \mathrm{ml}, 0.4$ $\mathrm{mM}$ methanolic solution containing DPPH radicals. The mixture was left in the dark for 30 min and the absorbance taken at $516 \mathrm{~nm}$ using UV-Visible spectrophotometer, JENWAY, GERMANY. The DPPH free radical scavenging ability was subsequently calculated.

\section{B. 2, 2'-azino-bis(3-ethylbenzthiazoline-6-} sulphonic acid) [ABTS] Radical Scavenging Ability

The ABTS scavenging ability of the extracts was determined according to the method described by Re et al. (1999). The ABTS was generated by reacting ABTS aqueous solution $(7 \mathrm{mmol} / \mathrm{l})$ with $\mathrm{K}_{2} \mathrm{~S}_{2} \mathrm{O}_{8}$ (2.45mmol/l, final concentration) in the dark for $16 \mathrm{~h}$ and adjusting the Absorbance at $734 \mathrm{~nm}$ to 0.700 with ethanol. The fortified cocoa powders and ginger drink were undiluted, while a
1:10 dilution of the other beverages was utilized for the assay. An aliquot of $0.2 \mathrm{ml}$ from each extract was then added to $2.0 \mathrm{ml}$ ABTS solution and the absorbance were measured at $734 \mathrm{~nm}$ after 15mins using the UV-Visible spectrophotometer, JENWAY, GERMANY. The trolox equivalent antioxidant capacity was subsequently calculated.

\section{Ferric Ion Reducing Antioxidant Power (FRAP) assay.}

The reducing property of the extracts was determined by assessing the ability of the extract to reduce $\mathrm{FeCl}_{3}$ solution as described by Oyaizu (1986). A $2.5 \mathrm{ml}$ aliquot of each extract was mixed with $2.5 \mathrm{ml} 200 \mathrm{mM}$ sodium phosphate buffer $(\mathrm{pH}$ 6.6) and $2.5 \mathrm{ml} 1 \%$ potassium ferricyanide. The mixture was incubated at $50^{\circ} \mathrm{C}$ for $20 \mathrm{~min}$. and then $2.5 \mathrm{ml} 10 \%$ trichloroacetic acid was added. This mixture was centrifuged at $650 \mathrm{rpm}$ for 10 min. The supernatant were collected and $5 \mathrm{ml}$ aliquot of each extract was mixed with an equal volume of water and $1 \mathrm{ml} 0.1 \%$ ferric chloride. The absorbance was measured at $700 \mathrm{~nm}$. The ferric ion reducing antioxidant property was then calculated.

\section{Iron $\left(\mathrm{Fe}^{2+}\right)$ Chelation Assay}

The $\mathrm{Fe}^{2+}$ chelating ability of the extracts was determined using a modified method of Minotti and Aust (1987) with a slight modification by Puntel et al., (2005). Freshly prepared $500 \mu \mathrm{M}$ $\mathrm{FeSO}_{4}(150 \mu \mathrm{l})$ was added to a reaction mixture containing $168 \mu \mathrm{l} 0.1 \mathrm{M}$ Tris- $\mathrm{HCl}$ (pH 7.4), $218 \mu 1$ saline and $100 \mu \mathrm{l}$ was taken from the 1:10 dilution of the extracts. The reaction mixture was incubated for $5 \mathrm{~min}$, before the addition of $13 \mu \mathrm{l}$ $0.25 \% \quad 1, \quad 10$-phenanthroline (w/v). The absorbance was subsequently measured at 510 $\mathrm{nm}$. The $\mathrm{Fe}$ (II) chelating ability was then calculated

\section{E. Determination of Total Phenol Content}

The total phenol content was determined according to the method of Singleton et al. (1999). A $100 \mu \mathrm{l}$ of the 1:10 dilution of the aqueous extracts was oxidized with $2.5 \mathrm{ml} 10 \%$ FolinCiocalteauô reagent $(\mathrm{v} / \mathrm{v})$ and neutralized with $2.0 \mathrm{ml}$ of $7.5 \%$ sodium carbonate. The reaction mixture was incubated for 40 minute at $45^{\circ} \mathrm{C}$ and the absorbance was measured at $765 \mathrm{~nm}$. The total 
phenol content was subsequently calculated as gallic acid $(10 \mathrm{mg} / 100 \mathrm{ml})$ equivalent.

\section{F. Determination of Total Flavonoid Content}

The total flavonoid content was determined using a slightly modified method of Meda et al. (2005), $0.5 \mathrm{ml}$ of $1: 2$ diluted sample was mixed with $0.5 \mathrm{ml}$ methanol, $50 \mu 110 \% \mathrm{AlCl}_{3}, 50 \mu 1 \mathrm{M}$ Potassium acetate and $1.4 \mathrm{ml}$ water, and allowed to incubate at room temperature for $30 \mathrm{~min}$. The absorbance of the reaction mixture was then measured at 415 $\mathrm{nm}$. The total flavonoid content was subsequently calculated using quercetin $(10 \mathrm{mg} / 100 \mathrm{ml})$ as standard.

\section{G. Determination of Vitamin C}

Vitamin $\mathrm{C}$ content of the aqueous extract was determined using the method of Benderitter et al., (1998). DNPH [2 g dinitrophenyl hydrazine, 230 $\mathrm{mg}$ thiourea and $270 \mathrm{mg} \mathrm{CuSO} 4.5 \mathrm{H} 2 \mathrm{O}$ in $100 \mathrm{ml}$ of $5 \mathrm{M} \mathrm{H}_{2} \mathrm{SO}_{4}$ ] was prepared and $75 \mathrm{\varepsilon l}$ of it was added to $500 \varepsilon$ reaction mixtures [300عl of the aqueous extracts and $100 \quad \varepsilon$ l of $13.3 \%$ trichloroacetic acid (TCA)]. The reaction mixture was subsequently incubated for $3 \mathrm{~h}$ at $37^{\circ} \mathrm{C}$, then $0.5 \mathrm{ml}$ of $65 \% \mathrm{H}_{2} \mathrm{SO} 4(\mathrm{v} / \mathrm{v})$ was added to the medium and the absorbance was measured at 520 $\mathrm{nm}$. The vitamin $\mathrm{C}$ content of the extracts was subsequently calculated using ascorbic acid $(10 \mathrm{mg} / 100 \mathrm{ml})$ as standard.

\section{Statistical Analysis}

All experiments were carried out in duplicates. Results are expressed as mean \pm standard error of the means. Pearsonôs correlation coefficient were calculated from the results using Microsoft Excel 2003.The results were statistically analyzed by Analysis of variance (ANOVA), and Duncan new multiple range tests. Statistical significance was accepted at PÒ0.05.

\section{RESULTS}

Total phenols, Flavonoids and Vitamin C content of the Beverages.

The results for the total phenols, flavonoid and vitamin $\mathrm{C}$ contents of the beverages are shown in Table 1. The results reveal that ginger drink had the lowest phenol content $(5.15 \pm 0.07 \mathrm{mg} / \mathrm{g})$, while coffee had the highest $(135.7 \pm 0.92 \mathrm{mg} / \mathrm{g})$. Ginger drink and the fortified cocoa powders $\left(\mathrm{FC}_{\mathrm{A}}, \mathrm{FC}_{\mathrm{B}}, \mathrm{FC}_{\mathrm{C}}, \mathrm{FC}_{\mathrm{D}}\right)$ had the lowest flavonoid content $(3.33 \mathrm{mg} / \mathrm{g}$ each), while the teas (Green tea, $\mathrm{T}_{\mathrm{A}}$ and $\mathrm{T}_{\mathrm{B}}$ tea samples) had the highest $(10.00 \mathrm{mg} / \mathrm{g})$.

The ginger drink and the fortified cocoa powders $\left(\mathrm{FC}_{\mathrm{A}}, \mathrm{FC}_{\mathrm{C}}, \mathrm{FC}_{\mathrm{D}}\right)$ were not significantly different at $\mathrm{P}>0.05$ in their phenol and flavonoid content. The total phenol content in green tea and tea sample A, showed no significant difference at $\mathrm{P}>$ 0.05 while coffee and tea sample $B$ were significantly ( $\mathrm{P}$ O 0.05 ) higher than the other beverages. Coffee had the highest value of vitamin C $(62.90 \mathrm{mg} / \mathrm{g})$, while ginger drink had the lowest value of $1.20 \mathrm{mg} / \mathrm{g}$. The pure cocoa powders were significantly (P Ò 0.05 ) higher in vitamin $\mathrm{C}$ than the fortified cocoa samples.

\section{Antioxidant activity of the Beverages}

The results for the evaluation of antioxidant activity of the Nigerian beverages as assessed by four in vitro methods (DPPH, ABTS radical scavenging ability, ferric reducing antioxidant property and Iron (II) chelating ability) are shown in Table 2.

The DPPH radical scavenging activity determination showed that green tea had the highest ability $(68.90 \%)$ while ginger drink had the lowest scavenging ability $(8.43 \%)$. The means of DPPH scavenging activity followed the descending order: green tea > tea sample $\mathrm{A}>$ coffee >tea sample B > pure cocoa powder A > pure cocoa powder $B>$ fortified cocoa powder $\mathrm{FC}_{\mathrm{D}}>\mathrm{FC}_{\mathrm{B}}>\mathrm{FC}_{\mathrm{C}}>\mathrm{FC}_{\mathrm{A}}>$ ginger drink.

The ABTS scavenging ability and ferric reducing antioxidant property (FRAP) revealed that green tea had the highest scavenging ability and reducing property of $1.048 \mathrm{mmol} / \mathrm{g}$ and $1235.88 \mathrm{mg} / \mathrm{g}$ respectively while ginger drink had the lowest value of $0.014 \mathrm{mmol} / \mathrm{g}$ and $44.28 \mathrm{mg} / \mathrm{g}$ respectively. The ABTS and FRAP antioxidant activity assay showed a similar trend with that observed for the DPPH assay.

The ferrous ion chelating abilities of the beverage studied showed that the pure cocoa powder $\left(\mathrm{PC}_{\mathrm{A}}\right.$ and $\mathrm{PC}_{\mathrm{B}}$ ) had the highest chelating ability of $43.27 \mathrm{mg} / \mathrm{g}$ and $38.46 \mathrm{mg} / \mathrm{g}$ respectively. The fortified cocoa powder $\mathrm{FC}_{\mathrm{A}}$, had the lowest ability of $3.85 \mathrm{mg} / \mathrm{g}$. The fortified cocoa powder $\mathrm{FC}_{\mathrm{A}}$ and $\mathrm{FC}_{\mathrm{B}}$; and tea sample $\mathrm{T}_{\mathrm{A}}$ were 
significantly different at (P Ò 0.05) .Coffee, ferrous ion chelating abilities that were not ginger drink, green tea and tea sample $\mathrm{B}$ had significantly different at (P Ò0.05).

Table 1: Phenolic Distributions (Total Phenol and Flavonoids) and Vitamin $\mathrm{C}$ in the Beverages.

\begin{tabular}{|c|c|c|c|}
\hline Beverage Samples & Total Phenol (mg/g) & Total Flavonoids (mg/g) & Vitamin C (mg/g) \\
\hline \multicolumn{4}{|c|}{ Fortified cocoa beverage } \\
\hline $\mathrm{FC}_{\mathrm{A}}$ & $5.19+1.84^{\mathrm{a}}$ & $3.33 \pm 0.00^{\mathrm{c}}$ & $9.15 \pm 1.20^{\mathrm{g}}$ \\
\hline $\mathrm{FC}_{\mathrm{B}}$ & $13.64 \pm 2.71^{\mathrm{b}}$ & $3.33 \pm 0.00^{\mathrm{c}}$ & $29.15 \pm 1.20^{\mathrm{d}}$ \\
\hline $\mathrm{FC}_{\mathrm{C}}$ & $5.84 \pm 0.92^{\mathrm{e}}$ & $3.33 \pm 0.00^{c}$ & $9.15 \pm 2.33^{\mathrm{g}}$ \\
\hline $\mathrm{FC}_{\mathrm{D}}$ & $9.09 \pm 1.27^{\mathrm{e}}$ & $3.33 \pm 0.00^{c}$ & $24.60 \pm 0.57^{\mathrm{e}}$ \\
\hline \multicolumn{4}{|l|}{ Pure cocoa powder } \\
\hline $\mathrm{PC}_{\mathrm{A}}$ & $41.56 \pm 2.71^{\mathrm{d}}$ & $5.00 \pm 2.36^{\mathrm{b}}$ & $49.60 \pm 0.57^{c}$ \\
\hline $\mathrm{PC}_{\mathrm{B}}$ & $32.47 \pm 9.18^{\mathrm{d}}$ & $5.00 \pm 2.36^{\mathrm{b}}$ & $48.75 \pm 0.64^{c}$ \\
\hline Coffee & $135.71 \pm 0.92^{\mathrm{a}}$ & $6.67 \pm 0.00^{\mathrm{b}}$ & $62.90 \pm 2.97^{\mathrm{a}}$ \\
\hline Ginger Drink & $5.15 \pm 0.07^{\mathrm{e}}$ & $3.33 \pm 0.00^{\mathrm{c}}$ & $1.20 \pm 0.56^{\mathrm{h}}$ \\
\hline \multicolumn{4}{|l|}{ Tea } \\
\hline Green tea & $99.90 \pm 1.69^{b}$ & $10.00 \pm 0.00^{\mathrm{a}}$ & $13.35 \pm 1.20^{\mathrm{f}}$ \\
\hline $\mathrm{T}_{\mathrm{A}}$ & $95.521 \pm .01^{b}$ & $10.00 \pm 0.00^{\mathrm{a}}$ & $57.05 \pm 1.77^{b}$ \\
\hline $\mathrm{T}_{\mathrm{B}}$ & $70.12+5.51^{\mathrm{c}}$ & $10.00+0.00^{\mathrm{a}}$ & $47.50 \pm 3.53^{\mathrm{c}}$ \\
\hline
\end{tabular}

Values are means \pm standard error of the mean (SEM).

Means having different superscript along the same column are significantly different at P Ò0.05.

Table 2: DPPH free radical scavenging ability, ABTS scavenging ability, ferric reducing antioxidant properties (FRAP) and $\mathrm{Fe}$ (II) chelating ability of the beverages.

\begin{tabular}{|c|c|c|c|c|}
\hline $\begin{array}{l}\text { Beverage } \\
\text { Samples }\end{array}$ & DPPH (\%) & ABTS $(\mathrm{mmol} / \mathrm{g})$ & FRAP (mg/g) & $\begin{array}{l}\mathrm{Fe}^{2+} \text { Chelation } \\
(\mathrm{mg} / \mathrm{g})\end{array}$ \\
\hline \multicolumn{5}{|c|}{ Fortified cocoa powder } \\
\hline $\mathrm{FC}_{\mathrm{A}}$ & $12.21 \pm 1.64^{\mathrm{d}}$ & $0.028 \pm 0.000^{\mathrm{f}}$ & $66.41 \pm 20.51^{\mathrm{f}}$ & $3.85 \pm 0.00^{\mathrm{e}}$ \\
\hline $\mathrm{FC}_{\mathrm{B}}$ & $24.24 \pm 4.37^{\mathrm{c}}$ & $0.022 \pm 0.001^{\mathrm{f}}$ & $154.20 \pm 8.64^{\mathrm{e}}$ & $22.12 \pm 4.08^{\mathrm{b}}$ \\
\hline $\mathrm{FC}_{\mathrm{C}}$ & $21.52+3.29^{c}$ & $0.028+0.000^{\mathrm{f}}$ & $105.34 \pm 10.50^{\mathrm{e}}$ & $17.31 \pm 2.72^{\mathrm{c}}$ \\
\hline $\mathrm{FC}_{\mathrm{D}}$ & $26.75+9.86^{\mathrm{c}}$ & $0.023+0.001^{\mathrm{f}}$ & $123.66+21.59^{\mathrm{e}}$ & $17.31 \pm 2.72^{c}$ \\
\hline \multicolumn{5}{|c|}{ Pure cocoa powder } \\
\hline $\mathrm{PC}_{\mathrm{A}}$ & $45.93 \pm 0.00^{\mathrm{b}}$ & $0.280 \pm 0.011^{\mathrm{e}}$ & $583.20 \pm 77.73^{\mathrm{c}}$ & $38.46 \pm 2.72^{\mathrm{a}}$ \\
\hline $\mathrm{PC}_{\mathrm{B}}$ & $55.52 \pm 6.71^{\mathrm{b}}$ & $0.238 \pm 0.011^{\mathrm{e}}$ & $407.64 \pm 53.97^{\mathrm{d}}$ & $43.27 \pm 4.08^{\mathrm{a}}$ \\
\hline Coffee(Nescafe) & $64.83 \pm 2.06^{\mathrm{a}}$ & $0.891 \pm 0.040^{\mathrm{c}}$ & $1063.36 \pm 134.94^{\mathrm{b}}$ & $21.15+8.16^{\mathrm{b}}$ \\
\hline $\begin{array}{l}\text { Ginger Drink } \\
\text { Tea }\end{array}$ & $8.43 \pm 2.51^{\mathrm{d}}$ & $0.014 \pm 0.001^{\mathrm{g}}$ & $44.28 \pm 2.16^{\mathrm{f}}$ & $18.27 \pm 4.08^{\mathrm{c}}$ \\
\hline Green tea & $68.90 \pm 2.06^{\mathrm{a}}$ & $1.048 \pm 0.037^{\mathrm{a}}$ & $1235.88 \pm 22.67^{\mathrm{a}}$ & $17.30 \pm 0.00^{\mathrm{c}}$ \\
\hline $\mathrm{T}_{\mathrm{A}}$ & $62.80+3.29^{\mathrm{a}}$ & $0.995+0.042^{b}$ & $1066.41+87.44^{b}$ & $12.50+1.36^{\mathrm{d}}$ \\
\hline $\mathrm{T}_{\mathrm{B}}$ & $59.89 \pm 0.83^{\mathrm{ab}}$ & $0.761 \pm 0.004^{\mathrm{d}}$ & $687.02 \pm 41.02^{\mathrm{c}}$ & $17.31 \pm 2.72^{\mathrm{c}}$ \\
\hline
\end{tabular}

Values are means \pm standard error of the mean (SEM).

Means having different superscript along the same column are significantly different at $\mathrm{P}<0.05$

\section{DISCUSSION}

Coffee, tea and cocoa powders are products that are increasingly used as functional beverages in Nigeria. The potential health benefits that are ascribed to them are due to the bioavailability of the antioxidant compounds they contain (Iwalewa et al., 2005).

The high phenol content in coffee could be due to the starting materials, roasting levels and brewing method (Ferruzi, 2010). 
Processing of raw cocoa beans involves fermentation, drying, and roasting (Wood and Las, 2001). This alters its chemistry. During cocoa fermentation, polyphenols are subjected to biochemical modifications through oxidation, polymerization and binding with proteins (Nazaruddin et al. 2006a).This leads to decreased solubility and astringency effects (Drying reduces the amount of polyphenols substantially by enzymatic browning ( Kyi et al. 2005). On the contrary, the roasting process, which is responsible for reducing bitter and acidic tastes, causes small changes in polyphenolic concentration (Misnawi et al. 2002; Nazaruddin et al. 2006b). The significantly (PÓ 0.05) higher phenolic contents of the pure cocoa powders $\left(\mathrm{PC}_{\mathrm{A}}, \mathrm{PC}_{\mathrm{B}}\right)$ than the fortified cocoa powders $\left(\mathrm{FC}_{\mathrm{A}}, \mathrm{FC}_{\mathrm{B}}, \mathrm{FC}_{\mathrm{C}}, \mathrm{FC}_{\mathrm{D}}\right)$ could be due to fermentation of the fortified cocoa powder during preparation.

Green tea had the highest phenolic and flavonoid contents of the teas studied. This may be due to the fact that in its processing, it is neither wilted nor oxidized (Graham, 2006). Wilting and oxidation cause changes in polyphenol content (Cabrera et al., 2006). Green tea has $30-40 \%$ epigallocatechingallate (EGCG). This result is in agreement with the earlier reported that teas contains more than 700 chemicals, among which the compounds closely related to human health are flavonoids, amino acids, vitamins $\mathrm{C}, \mathrm{K}$ and $\mathrm{E}$, caffeine and polysaccharides. It also agrees with reports where correlations were established between total phenolic and total flavonoid contents (Melo et al., 2006). Green tea had the highest DPPH scavenging ability.

DPPH is frequently used in the determination of free radical scavenging ability; however, it has the limitation of colour interference and sample solubility. Therefore, the free radical scavenging ability of the plant extracts were further studied using a moderately stable nitrogen-centered radical species: ABTS (2,2-azinobis (3ethylbenzo-thiazoline- 6-sulfonate). The ABTS radical based model of free radical scavenging ability has the advantage of being more versatile as both non-polar and polar samples can be assessed and spectral interference is minimized as the absorption maximum used is $760 \mathrm{~nm}$, a wavelength not normally encountered with natural products (Re et al., 1999). ABTS and DPPH free radical scavenging abilities follow the same trend. This was found to be; ginger drink $<$ fortified cocoa powders < pure cocoa powders $<$ tea sample $\mathrm{B}<$ coffee $<$ tea sample $\mathrm{A}<$ green tea in ascending order.

The techniques used for determining antioxidant activity, DPPH and ABTS free radical scavenging ability and FRAP had good positive correlations with the total phenol and flavonoid content of the beverages. (Table 3). This indicates that phenolic compounds are important contributors to antioxidant activity of the beverages. Similar results have been reported (Aikpokpodion and Dongo, 2010). It could be that phenolic compounds (where flavonoids is one of the main class), are known to be hydrophilic antioxidants and are the most abundant secondary metabolite in plants (Gil et al., 2002). Furthermore, good correlations were obtained from DPPH and ABTS free radical scavenging ability and FRAP indicating that the beverages had comparable activities in the three assays. High correlation is also found between these three assays in other plant derived samples (Connor et al., 2002).

Reducing power is a novel antioxidation defense mechanism; the two mechanisms that are available to affect this property are electron transfer and hydrogen atom transfer (Dastmalchi et al., 2007). The reducing powers of the beverage extracts were assessed based on their ability to reduce $\mathrm{Fe}(\mathrm{III})$ to $\mathrm{Fe}(\mathrm{II})$. The result follows the same trend as ABTS and DPPH free radical scavenging ability. This goes on to confirm that there is a correlation between total phenol contents and overall antioxidant capacity in foods. Neurodegenerative diseases and aging processes are associated with iron accumulation and this condition could be prevented by Fe chelators (Fraga and Oteiza, 2002). The ability of antioxidants to chelate and deactivate transition metals prevents such metals from participating in the initiation of lipid peroxidation and oxidative stress through metal-catalyzed reaction (Dastmalchi et al., 2007). The ability of the extracts to chelate transition metals is therefore considered to be due to an antioxidant mechanism (Oboh et al., 2007). The results revealed that all the extracts chelate Fe (II). Pure cocoa powders 
which were the highest chelators of iron, while the fortified cocoa powder $\left(\mathrm{FC}_{\mathrm{A}}\right)$ was the lowest chelator.The trend of this result is slightly similar with that of vitamin $\mathrm{C}$ distribution among the beverages. This similarity between the vitamin $\mathrm{C}$ content and the iron(II) chelating ability may confirm that vitamin $\mathrm{C}$ chelates heavy metals, reduces free radicals and suppress perioxidation thereby reducing the risk of artheriosclerosis, cardiovascular diseases and some cancers (Temple, 2000).
The low values for total phenol, flavonoid, Vitamin $\mathrm{C}$ and three antioxidant scavenging abilities (DPPH,ABTS and FRAP) of ginger tea, observed in this study, show that ginger tea exhibits low free radical scavenging abilities. Vitamin $\mathrm{C}$ has been reported to contribute to the antioxidant activities of plant food. Ascorbic acid is a good reducing agent and exhibits its antioxidant activities by electron donation (Oboh and Akindahunsi, 2004).

Table 3: Correlation coefficients of Total Phenol, Total Flavonoids, Vitamin C, Ferric Reducing Antioxidant Property (FRAP), ABTS Scavenging Ability, DPPH Free Radical Scavenging and Iron (II) Chelation Abilty.

\begin{tabular}{|c|c|c|c|c|c|c|c|}
\hline & $\begin{array}{l}\text { Total } \\
\text { Phenol }\end{array}$ & $\begin{array}{l}\text { Total } \\
\text { Flavonoid }\end{array}$ & $\begin{array}{l}\text { Vitamin } \\
\text { C }\end{array}$ & FRAP & $\begin{array}{l}\text { ABTS } \\
\text { Scavenging } \\
\text { ability }\end{array}$ & $\begin{array}{l}\text { DDPH Free } \\
\text { Radical } \\
\text { Scavenging }\end{array}$ & $\begin{array}{l}\text { Iron (II) } \\
\text { Chelatio } \\
\text { n Ability }\end{array}$ \\
\hline Total & & & & & & & \\
\hline $\begin{array}{l}\text { Phenol } \\
\text { Total }\end{array}$ & 1 & & & & & & \\
\hline Flavonoid & 0.818345 & 1 & & & & & \\
\hline Vitamin C & 0.647671 & 0.476165 & 1 & & & & \\
\hline $\begin{array}{l}\text { FRAP } \\
\text { ABTS }\end{array}$ & 0.95985 & 0.886159 & 0.578889 & 1 & & & \\
\hline $\begin{array}{l}\text { Scavenging } \\
\text { ability } \\
\text { DDPH Free } \\
\text { Radical }\end{array}$ & 0.95435 & 0.945882 & 0.539173 & 0.975472 & 1 & & \\
\hline $\begin{array}{l}\text { Scavenging } \\
\text { Iron (II) }\end{array}$ & 0.881724 & 0.85695 & 0.730549 & 0.925497 & 0.897748 & 1 & \\
\hline $\begin{array}{l}\text { Chelation } \\
\text { ability }\end{array}$ & -0.01306 & -0.10482 & 0.43899 & 0.047988 & -0.09632 & 0.294972 & 1 \\
\hline
\end{tabular}

\section{CONCLUSION}

The study revealed that; Green tea had the highest antioxidant activity, while coffee had good antioxidant capacity. Among the cocoa beverage, the pure cocoa powders $\left(\mathrm{PC}_{\mathrm{A}}\right.$ and $\left.\mathrm{PC}_{\mathrm{B}}\right)$ had more antioxidant capacity than the fortified cocoa powders $\left(\mathrm{FC}_{\mathrm{A}}, \mathrm{FC}_{\mathrm{B}}, \mathrm{FC}_{\mathrm{C}}, \mathrm{FC}_{\mathrm{D}}\right)$. Ginger drink may not be a suitable beverage to provide antioxidants as it had the lowest antioxidant activity of all the beverages.

\section{REFERENCES}

Aikpokpodion, P.E. and Dongo, L.N. (2010). Effects of fermentation intensity on polyphenols and antioxidant capacity of cocoa beans. Int. J. Sustain Crop Prod. 5(4): 66-70.

Aruoma, O.I. (2003). Methodological considerations for characterizing potential antioxidant actions of bioactive compounds in plant foods. Mutation Res. 523: 7-20.

Benderitter, M., Maupoil, V., Vergely, C., Dalloz, F., Briot, F., and Rochette, L. (1998). Studies by electron paramagnetic resonance of the importance of iron in the hydroxyl scavenging properties of ascorbic acid in plasma: Effects of iron chelators. Fundamentals Clin. Pharmacol. 12: 510ї 516.

Buijsse, B., Feskens, E.J, Kok, F.J. and Kromhout, D. (2006). Cocoa intake, blood 
Oboh and Omorege: Total Phenolics and Antioxidant Capacity of Some Nigerian Beverages

pressure, and cardiovascular mortality: the Zutphen Elderly Study. Arch. Intern. Med. 166(4): 411-417.

Cabrera,C, Artacho, R, and Gimenez. R (2006). Beneficial effects of green tea-a review. $J$. Am. Coll. Nutr. 2579-99.

Connor, A.M, Luby, J.J. and Tong, C.B.S. (2002). Variability in antioxidant activity in blueberry and correlations among different antioxidant activity assays. $J$. Am. Soc. Horticul. Sci. 127: 238-244

Dastmalchi, K., Dorman, H.J.D., Kosar, M. and Hiltunen, R. (2007). Chemical composition and in vitro antioxidant evaluation of a water soluble Moldavian balm (Dracocephalum moldavica L.) extract. Lebensm Wiss Technol, 40: 239ï 248.

Dreosti, I.E. (2000). Antioxidant polyphenols in tea, coffee and wine. Nutr.16: 7-8

Ferrazzano, G.F, Amato, I, A. Ingenito, A. De Natale and A. Pollio .A (2009). Anticariogenic effects of polyphenols from plant stimulant beverages (cocoa, coffee, tea). Fitoterapia, 89: 255-262,

Ferruzi, M. (2010). The influence of coffee and tea beverage composition on delivery of phenolics. Physiology and behaivour. 100(1)33 41.

Fraga, C.G. and Otezia, P.I. (2002): Iron toxicity and antioxidant nutrients. Toxicol. 180: 2332

Ghanim H, Sia C.L, Abuaysheh S, Korzeniewski K, Patnaik P, Marumganti A, Chaudhuri A and Dandona P. (2010). An antiinflammatory and reactive oxygen species suppressive effects of an extract of Polygonum cuspidatum containing resveratrol. J Clin Endocrinol Metab. 95(9): 1-8.

Gil, M.I., Tomas-Barberan, F.A., Hess-Pierce, B. and Kadar, A.A. (2002). Antioxidant capacities, phenolic compounds, carotenoids, and vitamin $\mathrm{C}$ contents of nectarine, peach and plum cultivars from California. $J$. Agric.Food Chem. 50: 4976-4982.

Graham, H.N. (2006). Green tea consumption and polyphenol chemistry. Preventive Med. 21(3): $334-50$

Gutteridge J.M.C. and Halliwell, B. (2000). Free radicals and antioxidants in the year 2000: A historical look to the future. Annals of the
New York Academy of Sciences. 899, 136147

Gyamfi, M.A., Yonamine, M. and Aniya, Y. (1999). Free radical scavenging action of medicinal herbs from Ghana: Thonningia sanguinea on experimentally induced liver injuries. Gen. Pharmacol. 32: 661 ï 667.

Iwalewa, E.O., Adewunmi, C.O., Omisore, N.O.A., Adebanji, O.A., Azike, C.K., Adigun, A. and Olowoyo, O.G. (2005). Proand antioxidant Effects and cytoprotective potentials 70 of nine edible vegetables in south-west Nigeria. J. Med. Food 8(4): 539544

Kyi, T.M., Daud, W.R.W., Mohammad, A.B., Samsudin, W.M., Kadhum, A.A.H, and Simon, J.A. (2005). Vitamin C and cardiovascular disease: A review. $J . A m$ Coll.Nutr.107-25.

Meda, A., Lamien, C.E., Romito, M., Millogo, J. and Nacoulma, O.G. (2005). Determination of the total phenolic, flavonoid and proline contents in Burkina Faso honey, as well as their radical scavenging activity. Food Chem. 91: 571 ï 577.

Melo, E.A., Lima, V.L.A.G., Maciel, M.I.S., Caetano, A.C.S., and Leal, F.L.L. (2006). Polyphenol, ascorbic acid and total carotenoid contents in common fruits and vegetables. Braz J. Food Technol. 9: 8910194

Minotti, G. and Aust, S.D. (1987). An investigation into the mechanism of citrate$\mathrm{Fe}^{2+}$ dependent lipid peroxidation. Free Radical Bio. Med. 3: 379 ï 387

Misnawi, S.J., Nazamid, S. and Jamilah, B. (2002). Activation of remaining key enzymes in dried under-fermented cocoa beans and its effect on aroma precursor formation. Food Chem. 78: $407 i ̈ 417$.

Nazaruddin, R., Osman, H., Mamot, S., Wahid, S. and Nor-Aini, I. (2006b). Influence of roasting condition on volatile flavor of roasted Malaysian cocoa beans. J. Food Processing Preserv. 30: 280 Ï 298.

Nazaruddin, R., Seng, L.K., Hassan, O. and Said, M. (2006a). Effect of pulp preconditioning on the content of polyphenols in cocoa beans (Theobroma cacao) during fermentation. Indust. Crops Prod. 24: 87ï 94.

Nicolle, C., Cardinault, N., Gueux, E., Jaffrelo, L., Rock, E., Mazur, A., Amouroux, P. and 
Rémésy, C. (2004). Health effect of vegetable-based diet: lettuce consumption improves cholesterol metabolism and antioxidant status in the rat. Clin. Nutr. 23: 605-614.

Oboh, G. and Akindahunsi, A.A. (2004). Change in the ascorbic acid, total phenol and antioxidant activity of some sun-dried green leafy vegetables in Nigeria. Nutr. Health, 18: $29 \ddot{i} 36$.

Oboh, G. and Rocha, J.B.T. (2007). Polyphenols in red pepper [Capsicum annuum var. aviculare (Tepin)] and their protective effect on some pro-oxidant induced lipid peroxidation in brain and liver. Eur. Food Res. Technol. 225: 239-247.

Oboh, G., Puntel, R.L. and Rocha, J.B.T. (2007). Hot pepper (Capsicum annuum, Tepin and Capsicum chinese, Habanero) prevents $\mathrm{Fe}^{2+}$ induced lipid peroxidation in brain-in vitro. Food Chem. 102: 178 ï 185

Oyaizu, M. (1986). Studies on products of browning reaction: antioxidative activity of products of browning reaction prepared from glucosamine. Japan J. Nutr. 44: $307 і ̈ 315$.

Pellegrini, N., Serafini, M., Colombi, B., Del rio,, D., Salvatore, S., Bianchi, M. and Brighenti, F. (2003). Total antioxidant capacity of plant foods, beverages and oils consumed in Italy assessed by three different in vitro assays. $J$. Nutr. 133: 2812-2819.

Puntel, R.L., Nogueira, C.W. and Rocha, J.B.T. (2005): Krebs cycle intermediates modulate thiobarbituric acid reactive species (TBARS) production in rat brain in vitro. Neurochem. Res. 30(2), $225 \mathrm{ï} 235$.

Rawell, H.M. and Kulling, S.E. (2007). Nutritional contribution of coffee, cacao and tea phenolics to human health. J. Consumer Protec. Safety 2(4): 399-406.

Re, R., Pellegrini, N., Proteggente, A., Pannala, A., Yang, M. and Rice-Evans, C (1999). Antioxidant activity applying an improved
ABTS radical cation decolorisatioan assay. Free Rad Bio Med. 26: 1231 Ï 1237.

Richelle, M., Tavazzi, I. and Offord, E. (2001). Comparison of the antioxidant activity of commonly consumed phenolic beverages (coffee, cocoa, tea) prepared per cup serving. J. Agri.c Food Chem. 49: 3438-3442.

Schroeter, H., Boyd, C., Spencer, J.P.E., Williams, R.J., Cadenas, E. and Rice-Evans, C. (2002). MAPK signaling in neurodegeneration: Influences of flavonoids and of nitric oxide. Neurobiol. Aging, 23: 861 ï 880.

Silva, E.M., Souza, J.N.S., Rogez, H., Rees, J.F and Larondelle, Y. (2006). Antioxidant activities and polyphenolic contents of fifteen selected plant species from Amazonian region. J. Food Chem. 9: 546-593.

Singleton, V.L., Orthofor, R. and LamuelaRaventos, R.M (1999). Analysis of total phenols and other oxidation substrates and antioxidants by means of Folin-Ciocaltau reagent. Methods Enzymol. 299: 152 ï 178.

Sun, J., Chu, Y., Wu, X. and Liu, R. (2002). Antioxidant and antiproliferative activities of common fruits. J. Agric. Food Chem. 50: 7449-7454.

Talib, M.Z.M. (2005). The kinetics of polyphenol degradation during the drying of Malaysian cocoa beans. International J. Food Sci. Technol. 40: $323 \ddot{i} 331$.

Temple, N.J. (2000). Antioxidants and disease: more questions than answers. Nutr. Res. 20: 449ï 459.s

Wood, G.A.R. and Lass, R.A. (2001). Cocoa. $2^{\text {nd }}$ edition. MPG Books ltd Bodmin Cornwal 587-597.

Yashin, Y.I., Nemzev, B.V., Ryzhnew, V.Y., Yashi, A.Y., Cherhousova, N.I. and Fedina. P.A. (2010). Creation of a data bank for content of Antioxidants I food product by Amperometric methods. Mol. 15: 7450-7466. 